\title{
Research and Practice on the Construction of Bilingual Teaching Mode of Automobile Major in Higher Vocational Education
}

\author{
Yan Zhao, Xiaowei Wu, Suyun Shi
}

Henan College of Transportation, Zhengzhou 451460, Henan, China. E-mail: brianzhaofx@163.com

Fund Project: The 2019 Henan College of Transportation Education and Teaching Reform Project "Research and Practice of International Students Bilingual Teaching Mode" (2019JG044) Phased results, 2019 Henan Higher Education Teaching Reform Research and Practice Project "Based on the Concept of Skilled Master Training The Phased Achievements of "Research on the Construction and Application of Golden Courses in Vocational Colleges" (2019SJGLX737)

Abstract: The implementation of bilingual teaching in automotive majors in higher vocational colleges is not only to meet the needs of the development trend of the automotive industry, but also to meet the needs of vocational students to enter professional positions after graduation. However, in the specific teaching process, all vocational colleges are faced with this is due to the lack of bilingual teachers in automotive majors, poor English foundation for vocational automotive students, poor English learning ability, and lack of bilingual teaching materials for automotive majors. How to construct a reasonable bilingual teaching model has become an important topic for automotive teachers in higher vocational colleges. This article selects foreign original textbooks and self-compiled bilingual teaching textbooks, increases online and offline training, improves professional teachers, and tries various bilingualism The teaching mode explores the path of bilingual teaching practice in the automotive major of higher vocational colleges, and aims to promote the training process of international talents in the automotive major of higher vocational education.

Keywords: Higher Vocational Colleges; Automobile Major; Bilingual Teaching; Practice

Bilingual teaching refers to teaching in a second language other than the mother tongue. The bilingual teaching in higher vocational colleges here specifically refers to English teaching. In view of the increasingly international trend of the automotive industry, we want to enhance the comprehensive strength of China's automotive industry. It is inseparable from learning from the world's automobile powers, and English, as the world's common language, should be a necessary quality for automobile professionals. Therefore, in addition to focusing on the teaching of students' professional theoretical knowledge and vocational skills, the automobile majors of vocational colleges must incorporate English into the teaching of automobile majors to cultivate talents with both automobile professional skills and English ability for the Chinese automobile industry.

\section{The necessity of bilingual teaching in higher vocational automobile majors}

\subsection{Conform to the development trend of the automotive industry}

The development of the automobile industry is becoming increasingly international. Under the guidance of the "One Belt, One Road" national strategy, China's automobile industry is increasing its close cooperation with international industrial powers. A large number of joint ventures in the production, maintenance and sales of automobiles and auto parts will the marketing strategy center and technology research and development center are transferred to China. At the same time, China's automobile industry is also learning from the valuable experience of these industrial powers, seeking opportunities to go abroad and into the world, aiming to raise China's automobile industry to the world's advanced level. As a student of automobile major

Copyright $(2020$ Yan Zhao et al.

doi: 10.18686/ahe.v4i10.2952

This is an open-access article distributed under the terms of the Creative Commons Attribution Non-Commercial License (http://creativecommons. org/licenses/by-nc/4.0/), which permits unrestricted non-commercial use, distribution, and reproduction in any medium, provided the original work is properly cited. 
in higher vocational colleges, you should follow the trend of the international development of the automobile industry. While studying automobile professional technology, you must have a corresponding level of English communication. Therefore, it is of great significance to carry out bilingual teaching in the automobile major of higher vocational colleges.

\subsection{Meet the requirements of automotive professional positions}

Based on the fact that China's automobile industry started relatively late, most of the current international advanced technology documents related to the automobile industry are in English. With the development of China's automobile market, the number of imported automobiles, auto parts and automobile production equipment is increasing. The accompanying hardware, software, manuals, materials, technical parameters and maintenance manuals are all in English. For vocational automotive graduates who will be engaged in automotive professional positions, English proficiency has become an essential requirement. It can be seen that bilingual teaching in higher vocational automotive majors meets the international requirements of automotive professional positions ${ }^{[1]}$.

\subsection{To fill the talent gap in the automotive industry}

China's automobile industry is in a stage of rapid development, and there is a greater demand for automotive professionals, especially for practical automotive professionals. In addition to solid automotive professional theories and superb automotive professional practical skills in the measurement standards of talents, it is also necessary to have a certain English communication ability to facilitate communication and learning with the international automotive industry, so it is necessary to promote higher vocational education in the bilingual teaching of automotive majors The comprehensive literacy of students can fill the current gap of international talents in the automotive industry.

\subsection{Learning to maintain English application ability}

Most vocational colleges focus on professional theory and practice, and there are fewer class hours for public courses such as English, which is not conducive to the improvement of vocational students' English level. In all walks of life in today's society, English is a necessary basic skill. Bilingual teaching in the automobile major provides an effective way for higher vocational students to learn English.

\section{The current situation and problems of bilingual teaching in higher vocational automobile majors}

\subsection{The strength of bilingual teaching teachers is weak}

Carrying out bilingual teaching in higher vocational auto major is a challenge for higher vocational auto teachers. Judging from the current English level of the automotive professional teachers in higher vocational schools, there is a situation of unevenness. Some teachers have excellent automotive professional teaching capabilities, but they are more difficult in oral English, especially when teaching professional knowledge in English. There are often certain pronunciation and grammatical errors. In view of the lack of teachers capable of bilingual teaching in automotive majors, it is still difficult for the bilingual teaching model of higher vocational automotive majors to achieve the expected results ${ }^{[2]}$.

\subsection{Higher vocational students have poor English foundation}

Among the automobile majors in higher vocational colleges, the overall level of English is not high, the foundation is uneven, and the students' acceptance of bilingual teaching is completely different. When teachers face the bilingual teaching of automotive professional courses with a large number of students, the proportion of English teaching is restricted, which leads to a large difference in the learning effect of students and low learning enthusiasm, which affects the actual effect of bilingual teaching to a certain extent.

\subsection{There are fewer bilingual textbooks for automotive majors}

Faced with the many types of automotive majors, the existing related bilingual textbooks are limited to a simple introduction to the automotive module. For deeper automotive fault diagnosis and maintenance, there are few matching bilingual textbooks. The lack of textbooks leads to the loss of teachers' teaching It provides a strong basis and restricts the promotion of bilingual education in higher vocational automotive majors.

\subsection{Outdated bilingual teaching methods for automotive majors}

After investigation, most of the higher vocational colleges that offer bilingual teaching of automobile majors still use traditional translation methods. That is, the existing Chinese textbooks or course contents are directly translated into the corresponding English, and the teacher in the class will use Chinese and English to speak each time. In this process, not only 
the original workload of the teacher is greatly increased, but also many content ambiguities and understanding deviations caused by language differences and translation skills will be generated, resulting in poor bilingual teaching effects.

\section{Discussion on the construction of bilingual teaching mode of automobile major in higher vocational education}

\subsection{Self-selected bilingual teaching materials}

Facing the lack of bilingual textbooks for automobile majors in higher vocational colleges, higher vocational colleges should start with two aspects: self-selection and self-editing. On the one hand, for qualified higher vocational colleges, a part of the original English textbooks can be selectively introduced, so that students can integrate with international automotive professional knowledge to the greatest extent, but in view of the high cost of introducing the original English textbooks, and for some For vocational students, the original textbook is difficult to learn, so it is not applicable to all vocational colleges ${ }^{[3]}$. On the other hand, higher vocational colleges can organize in-depth investigations by experts, scholars and full-time teachers. According to the current situation of automobile teaching and the needs of automobile companies for talents, with the assistance of English teachers, they can compile their own documents that meet the needs of bilingual teaching in China's higher vocational automobiles The teaching materials can not only better serve bilingual teaching, but also improve the English teaching level of automobile teachers.

\subsection{Strengthen the construction of professional teachers}

The guarantee of professional teachers is the basis for the implementation of bilingual teaching mode. Higher vocational colleges should strengthen teachers' English training. Increase investment in the construction of bilingual teaching teachers, formulate reasonable and effective bilingual teacher training plans, regularly assign professional teachers to foreign first-class higher vocational colleges for exchanges and training according to professional construction needs, and introduce foreign experts to regularly exchange lectures and so on. And make use of online and offline English teaching resources to train professional teachers in English proficiency.

\subsection{Try a variety of bilingual teaching modes}

In view of the characteristics of the automobile profession, teachers should explore multiple modes when carrying out bilingual teaching. First, aiming at the job environment of higher vocational graduates after employment, conduct scenario simulation training and role play, so that schools can improve their English ability in a good language atmosphere. Second, for the key professional vocabulary of the automobile major, multimedia teaching methods can be used to deepen the impression of students. Third, carry out automobile-themed activities to allow students to complete established tasks in English and fully mobilize students' learning enthusiasm. When exploring the bilingual teaching mode in the automobile major of higher vocational colleges, it is necessary to give students a gradual process, from easy to difficult to penetrate layer by layer, persist in English learning, and achieve the dual improvement of professional level and English ability.

\section{Conclusion}

Under the trend of education and talent internationalization, it is imperative to implement bilingual teaching in automotive majors in higher vocational colleges. However, how to implement it smoothly and achieve better results is a big challenge. It requires higher vocational colleges themselves and teachers. In bilingual teaching, the bilingual teaching objectives of automotive majors in higher vocational colleges are more targeted, requiring students to master the automotive major-related listening, speaking, reading, and writing, be able to accurately read the English version of automotive materials, and simple English communication skills. In the end, it will achieve the dual improvement of higher vocational auto professionals in auto professional technology and English expression ability, and truly realize the goal of cultivating international auto professionals.

\section{References}

1. Yan Y. Research on the training strategies of bilingual teaching talents in higher vocational education in the new period. Education Teaching Forum 2020; (1): 64-65.

2. Cui S. Research and practice of "bilingual teaching" teaching reform in higher vocational colleges. Shanxi Youth 2019 ; (22): 56.

3. Wei J. Thinking of bilingual teaching in higher vocational colleges. Science and Technology Information $2019 ; 17$ (25): 167-168. 